\title{
EROSIONAL-DENUDATIONAL VALLEYS AND THEIR SIGNIFICANCE FOR THE RECONSTRUCTION OF THE LATE GLACIAL ENVIRONMENTAL CONDITIONS (THE DRAWSKO LAKELAND, NW POLAND)
}

\author{
Renata PaluszKiewicz \\ Adam Mickiewicz University, Institute of Geoecology and Geoinformation, Department of Geoecology, \\ Poznań, Poland
}

Manuscript received: July 7, 2011

Revised version: September 2, 2011

\begin{abstract}
Paluszkiewicz R., 2011. Erosional-denudational valleys and their significance for the reconstruction of the Late Glacial environmental conditions (NW Poland - the Drawsko Lakeland). Quaestiones Geographicae 30(3), Bogucki Wydawnictwo Naukowe, Poznań, pp. 71-81, 5 Figs. ISBN 978-83-62662-75-3. ISSN 0137-477X. DOI 10.2478/ v10117-011-0028-7
\end{abstract}

AвSTRACт. The article presents the morphological-lithological development and operation of dry erosional-denudational valleys located on morainic uplands in the Drawsko Lakeland. A detailed research was carried out on the morainic upland of the Buślarka and Piaski Pomorskie area. A geodetic study made it possible to identify over ten NW-SE and N-S oriented erosional-denudational valleys, clearly marked in the relief. They are small landforms: their length does not exceed $100 \mathrm{~m}$, and the depth of incision reaches $4 \mathrm{~m}$. Their exact morphometric description with the help of GIS methods and a detailed study of lithofacies characteristics of their deposits provided an insight into their operation. They follow a Late Glacial pattern in which Late Vistulian erosion only rejuvenated the already existing older forms.

KeYwORDs: erosional-denudational valleys, upland scarps, morphometric features, Drawsko Lakeland, West Pomerania

Renata Paluszkiewicz, Adam Mickiewicz University, Institute of Geoecology and Geoinformation, Department of Geoecology, Dzięgielowa 27,61-680 Poznań, Poland, e-mail: reniach@amu.edu.pl

\section{Introduction}

The earliest works dealing with the genesis and later the age of dry valley landforms rested on an analysis of their morphometric features (Passarge 1924, after Klatkowa 1965). The opinion about the glacial or postglacial age of those landforms in northern Poland was first advanced by Okołowicz (1947). The first postwar studies by Polish authors concerning denudational landforms in the postglacial region only appeared in the 1960s, e.g. Marsz's (1964) concerning the Kashubian Pradolina, Churska's (1965) dealing with the Warta-Noteć Pradolina and the Drwęca valley, or Kostrzewski's (1963) from the Leszno Upland. Those authors focused on the systems of small, dry valleys dissecting scarp zones. They were in agreement about the "periglacial character of the relief", although their opinions differed as to the period of intensive development of the valleys. According to Marsz, the chief stages of their formation occurred in the interstadial pe- 
riods of the Late Glacial, while Churska was of the opinion that those processes took place in the cold periods.

The literature on dry valleys largely deals with the upland regions of Poland (e.g. Dylik 1953; Jahn 1956; Klatkowa 1965; Maruszczak 1968). The latest studies addressing denudation issues, still infrequent, also tackle the effect of human activity on its pattern (Borówka 1992, 1994; Smolska 2002; Szpikowski 2005). Despite a considerable body of literature on the subject, studies of the operation and formation of valley landforms in postglacial areas, including the Drawsko Lakeland, are still scarce.

The aim of this article is to describe the development and operation of erosional-denudational valleys. Through a geomorphological analysis of selected valleys in the Drawsko Lakeland, it was demonstrated how significant they were for the reconstruction of Late Glacial conditions.

\section{Study area}

In geographical terms (Kondracki 2000), the study area lies in the macro-region of the West Pomeranian Lakeland (sub-province of the South- ern Baltic Lakeland) and is a part of the Drawsko Lakeland meso-region (Fig. 1). The research covered $289.51 \mathrm{~km}^{2}$ of the catchment of the Dębnica river, a left-bank tributary of the Parsęta. The principal hydrographic artery of this area, the Dębnica carries water away from postglacial uplands. There are two terraces in the valley floor: the floodplain and a cut-and-built terrace above it. With a channel gradient of $0.5 \%$, the river meanders within its valley floor, whose width grows considerably, locally to more than $1 \mathrm{~km}$. In the scarp zones of morainic uplands and on slopes of valleys there are distinct small erosional-denudational valleys and gullies, either drained episodically or dry. On the slopes of the Dębnica valley numerous such erosional-denudational valleys were found to occur (Paluszkiewicz 2007, 2008, 2009). A detailed research was conducted in two areas: the Buślarka upland zone and the Piaski Pomorskie upland zone (Fig. 1).

\section{Morainic upland in the Buślarka area}

The study area embraced the scarp of the morainic upland in the Buślarka area (some $2 \mathrm{~km} \mathrm{NE}$ of Połczyn Zdrój). According to the geomorpho-

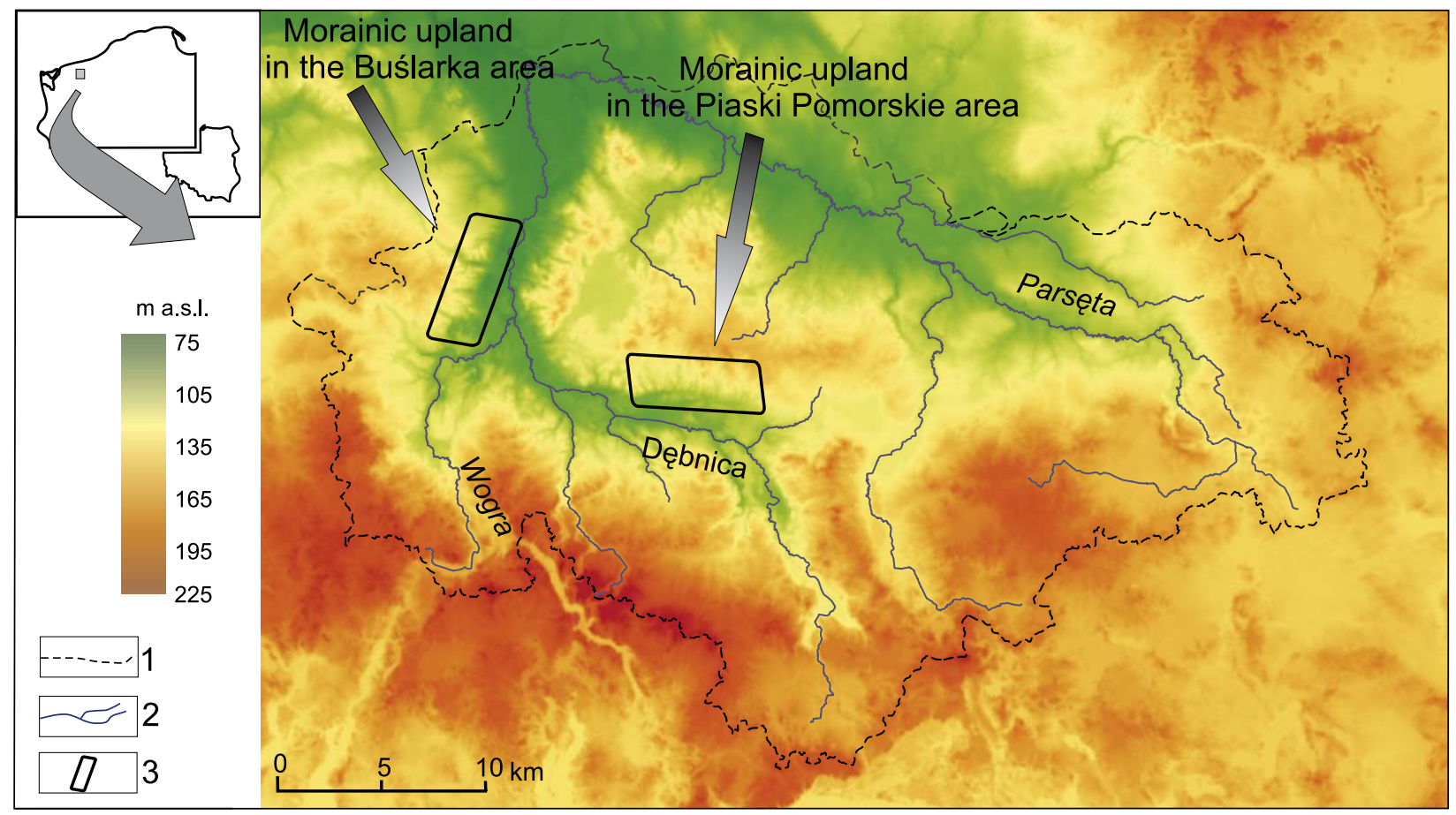

Fig. 1. Location of study area (Global data base GTOPO30 http://edcdaac.usgs.gov/gtopo 30/gtopo30.html processed by A. Stach).

1 - watershed, 2 - river network, 3 - study area. 
logical sketch on the Połczyn Zdrój sheet (Dobracka 2009; Fig. 2), an undulating morainic upland extends here in the hinterland of morainic hills, and its elevation varies between $120 \mathrm{~m}$ a.s.l. in the northern part to $180 \mathrm{~m}$ a.s.l. in the south. Its feature of special interest is its scarp running NE-SW. What give its surface a unique character are the upper and middle sections of erosionaldenudational valleys that rise in its area. The wide zone of the long slope on the eastern side of the Buślarka Hills is strewn with numerous denudational valleys. The slope zone extends from the top of the upland at an altitude of $150 \mathrm{~m}$ a.s.l. down to $80 \mathrm{~m}$ a.s.l. in a belt varying from 0.7 to $1.2 \mathrm{~km}$ in width. As Dobracka (2009) reports, this highly denudated slope is built of sandy glaciofluvial deposits underlying glacial tills. The marked inclination of the upland surface towards the Dębnica valley has given rise to the appear- ance and development of erosional-denudational valleys. Their orientation is perpendicular to the valley axis and they feature distinctly in the relief, being incised into the upland surface to a depth of 2 to $4 \mathrm{~m}$.

Along the entire length of the scarp extending for some $4 \mathrm{~km}$, a total of $16 \mathrm{NW}$-SE-oriented erosional-denudational valleys were identified, clearly marked in the relief. All of them are dry, but three display a permanent runoff. Most of them are single landforms varying in length from more than ten to more than $100 \mathrm{~m}$, but there are also some that consist of a trunk valley and several lateral ones.

Within the scarp zone, in its southern and central parts, the valleys are incised in sands and gravels with an admixture of boulders. Those deposits lie on the land surface under a thin cover of glacial tills and sands, and crop out on the
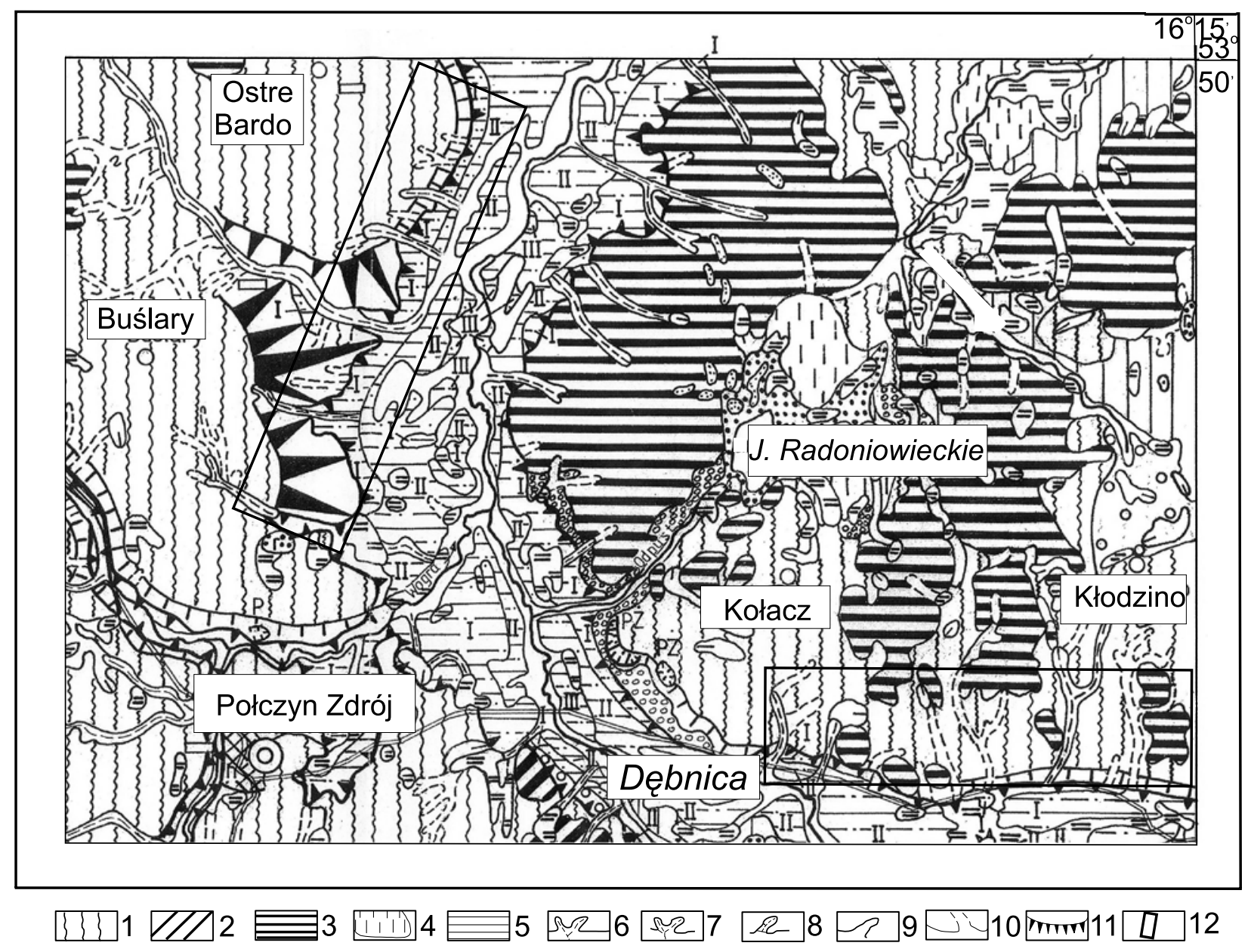

Fig. 2. Geomorphological sketch of the research area (Dobracka 2009).

1 - undulated ground morainic plateau, 2 - accumulation end moraine, 3 - kames, kame plateau, 4 - final cavity (melt), 5 - river terracy 2,0-5,0 m n.p. river, 6 - valleys, ravines and young cut erosion, inseparable, 9 - dry valleys, 10 - denudation valleys, 11 - long slopes, 12 study area. 
slopes of the Dębnica valley, also in the region of the Buślarka Hills. In the northern part of the scarp, certain differences in the deposits can be observed: the outlet sections of the valleys are incised in sand-gravel deposits, while their middle and upper reaches are incised in sand-silt-gravel deposits, which occur here in the form of covers of varying thickness on ground-morainic tills. The thickness of deposits differs; it attains a maximum of $5 \mathrm{~m}$.

\section{Morainic upland of the Piaski Pomorskie area}

The scarp of the morainic upland of the Piaski Pomorskie region shows a W-E orientation (Fig. 2). Its length is about $6 \mathrm{~km}$, and its absolute altitude ranges from 100 to $125 \mathrm{~m}$ a.s.l. The scarp is dissected by numerous small, dry erosionaldenudational valleys differing in length and the depth of channel incision. Along the length of the scarp an inventory was made of 20 dissections running N-S, clearly discernible in the relief. Less distinct in the relief are the alluvial cones accompanying the valleys.

By the subzones of the Parsęta lobe distinguished by Karczewski (1989), the study area is situated on the highest, $7^{\text {th }}$, level of the morainic upland of the northern slope of Pomerania. The dominant elements of the relief are an undulating morainic upland in the north and valleys and cut-and-built meltwater plains in the south. In the western part there are dead-ice morainic hills.

\section{Study methods}

In order to make the right choice of landforms for a representative study even before fieldwork, an analysis was made of archival topographic maps at a scale of 1:10 000, which allowed such a selection. Because of the insufficient accuracy of the topographic maps and the size of the valleys, it was necessary to perform direct topographic measurements of those landforms. Their accuracy is especially important because of the propagation of error when calculating derivative topographic parameters (gradient, length of dissections, floor width, depth). The measure- ments were carried out using Elta RAR 50 equipment and, when necessary, supplemented with tachymetric measurements. Such precise measurements of the erosional dissections, combined with geomorphological mapping with the use of GIS methods, allowed making height profiles as well as transverse and longitudinal cross-sections of the valleys.

To solve the research problem posed, it was of fundamental importance to determine the geological structure of the study area. The basic sources of information were exposures and profiles made within them, while borings played an auxiliary role in this task. An analysis of deposits in the exposures provided a basis for a reconstruction of sedimentation conditions. In addition, cuttings and exposures were made on the slopes and in the floors of the landforms examined.

The next research stage involved a laboratory examination of samples taken in the field. Laboratory analyses and the accompanying indoor processing of their results embraced the following:

- an analysis of the mechanical composition of deposits using Cassagrande's areometricsieve method modified by Prószyński (Racinowski 1973; Płochniewski 1986),

- determination of the calcium carbonate $\left(\mathrm{CaCO}_{3}\right)$ content using Scheibler's apparatus, and

- an analysis of the abrasion grade of quartz grains using Krygowski's (1964) mechanical graniformametry method for the fractions of $1.25-1.0 \mathrm{~mm}$ and $1.0-0.8 \mathrm{~mm}$.

To handle the results obtained during fieldwork and laboratory analyses and to process cartographic material, use was made mostly of the software available in the Department of Geoecology and the Faculty of Geographical and Geological Sciences of Adam Mickiewicz University in Poznań.

\section{Morphometric features of the valleys and their paleogeographical reading}

The slope asymmetry of dry valley landforms is a widely known phenomenon and has been frequently addressed in the literature (e.g. Mojski 1950, Jahn 1956, Maruszczak 1956, Churska 1965, 
Klatkowa 1965, Gołębiewski 1981). It is thought to be connected primarily with the dominant role of climatic factors responsible for differences in the processes working on the opposite slopes and their dynamics. When analysing the transverse profiles of the valleys in the study area, this dependence was found to hold for the Piaski Pomorskie scarp zone (Paluszkiewicz 2009). The profiles show an asymmetry in which the slope with an eastern exposure is gentler (Figs. 3, 4). Differences in the gradients of the steep and the gentle slope attain a few degrees $\left(2^{\circ}-9^{\circ}\right)$. In the valleys that have formed in the Buślarka upland zone, differences in the inclination of the $\mathrm{E}$ and $\mathrm{W}$ slopes are slight, about $2^{\circ}$. The asymmetry is slight, but significantly regular; it is as a rule 'heat asymmetry': the slopes with a warm exposure tend to be steeper. A similar dependence was observed by Churska (1965) in dry valleys of northern Poland, within the Kujavia Stage. According to Tricart (1950), on slopes with a southern exposure permafrost is poorly developed, which makes them defrost and dry quickly in spring. Thus, the role of regelation and cryoturbation in slope modelling is small. On shaded north-facing slopes permafrost is better developed and the slopes are made gentler by intensive slope processes. The asymmetry suggests that the valleys started to form already in the Late Vistulian. Another indication is the absence of alluvial cones at their outlets.
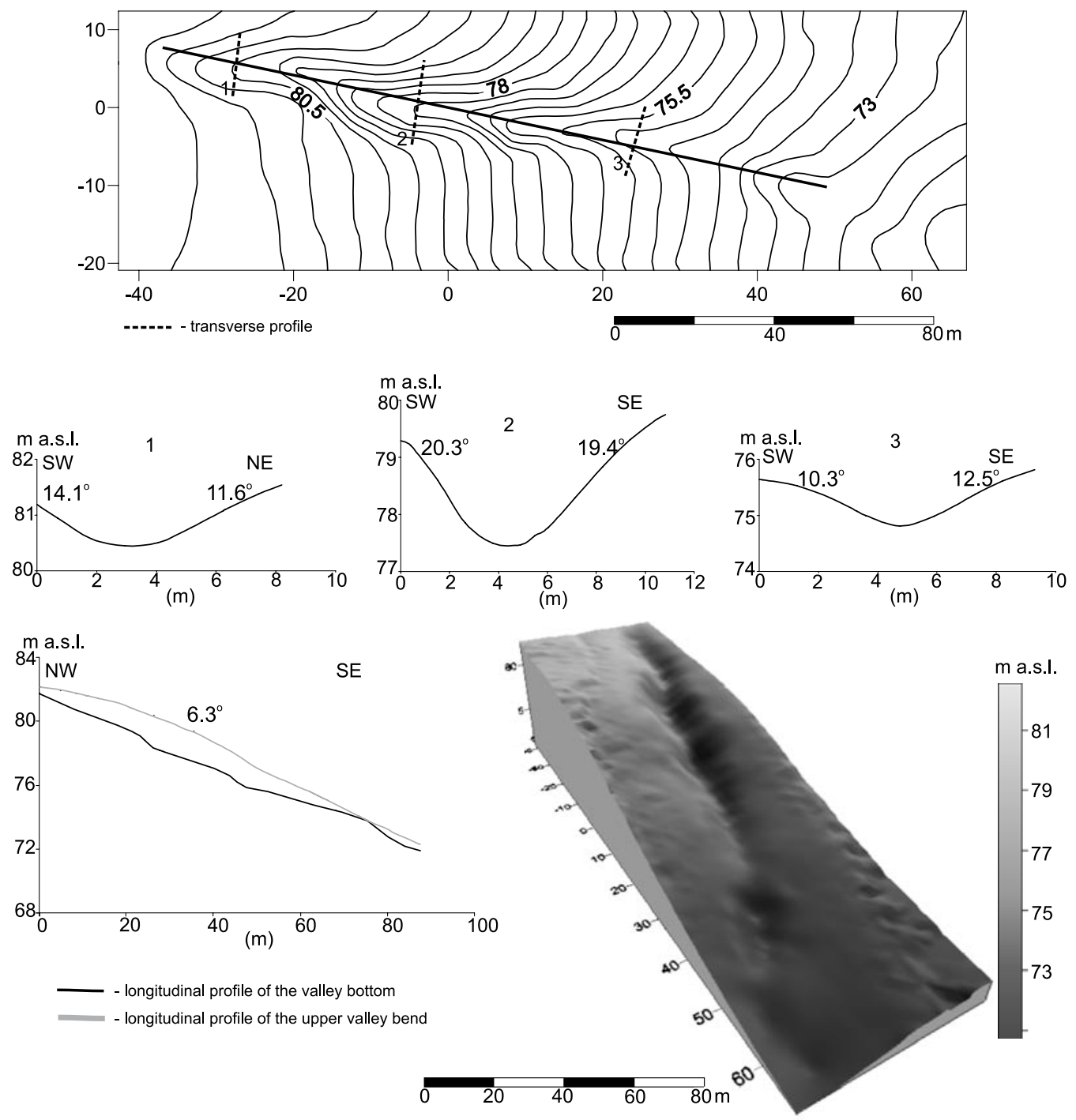

Fig. 3. Hypsometric map of erosional-denudation valley together with its long and transverse profiles for Buślarki area. 
The dissections under study differ in their mode of formation and morphometric features. In terms of size, they are small landforms (Figs 3, 4). Most are single valleys 30 to $130 \mathrm{~m}$ long, but there are also some consisting of a trunk valley joined by one or several lateral ones (Fig. 4).

Lateral valleys hang above the floor of the trunk valley, which is evidence of their later formation. Their length is small (a maximum of a few metres). Most have a flat floor. The depth of the incisions displays considerable differences along the entire length; the deepest incised sections are the central ones, to about 3-4 m, and the least incised are the outlet ones. The long profile, running W-E and NW-SE, is usually even, although some dissections have a stepped profile. The analysis of the long profiles of the valleys clearly shows their middle parts to have undergone the deepest incision in relation to the original surface. The profile gradient is about $6^{\circ}$ on average. The floor becomes flatter down-valley and the boundary between the floor and the slopes grows more distinct. This is a result of the accumulative character of the floor, on which has gathered material transported from the up-valley sections. The gradient decreases towards the outlet of the valleys. In turn, their transverse profiles (S-N and SW-NE oriented) show the greatest gradients in the middle parts, up to a maximum of $26^{\circ}$, while at the outlet they range from $10^{\circ}$ to $23^{\circ}$.
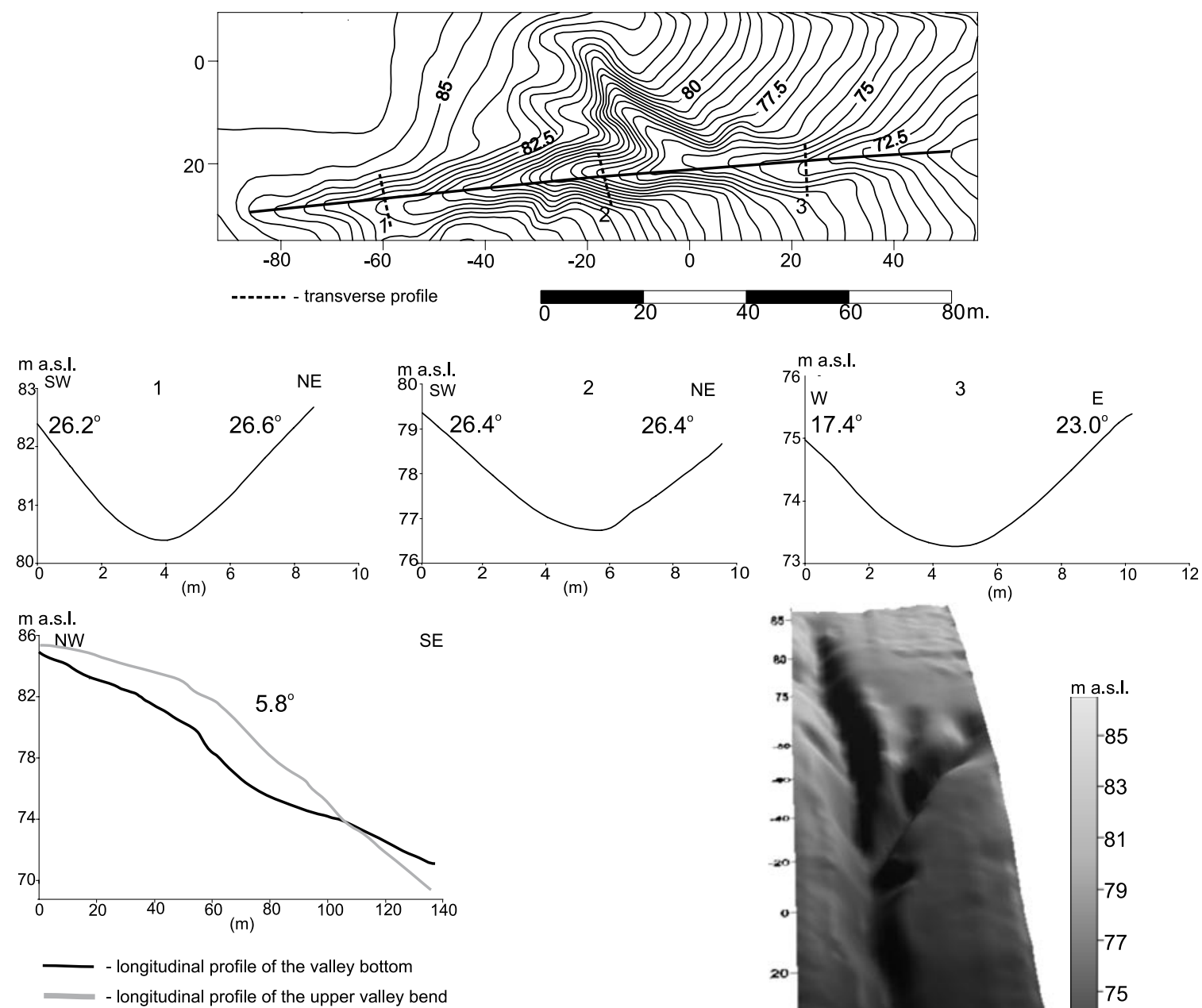

SE

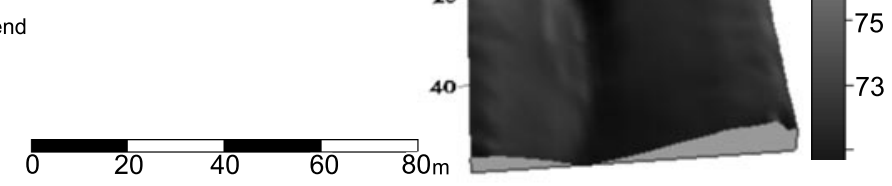

Fig. 4. Hypsometric map of erosional - denudation valley together with its long and transverse profiles for Piaski Pomorskie area. 


\section{Lithofacies characteristics of deposits}

To determine the lithofacies variability of deposits, they were characterised on the basis of cuttings and hand borings made both in the valleys and in the upland zone. The details allow some generalisations and the tracing of lithofacies patterns characteristic of the head and outlet sections of the studied landforms. The dominant group of deposits is fine sands accounting for $41.3 \%$ of the population (44 samples). The proportions of the remaining fractions look as follows: medium sand $-36 \%$, coarse gravel $-17.4 \%$, fine gravel $3.8 \%$, medium gravel $-1.3 \%$, and fine silt $-0.2 \%$. In the head zones of a decided majority of the valleys one can distinguish three basic lithofacies:

- a sand-stone near-surface layer (the initial stage in the development of the valleys);

- a layer of the erosional pavement; and

- a series of massive fine and medium-grained sands.

The series observed in the lowest parts of the erosional-denudational valleys are largely a continuation of those in the central sections. The following lithofacies were distinguished:

- a series of fine yellow sands, genetically connected with surface runoff and slope wash,

- a stone-gravel layer providing resistance against a further lowering of the erosional base of the valleys, and

- fine sands with flow-derived gravel-stone intercalations, which are a continuation of the in situ series of the central sections of the valleys.

To learn about differences in the sedimentary environment in the head and outlet zones of the valleys, a comparison was made of the frequency curves of deposits (Fig. 5). There is a readily visible difference in their shapes. Those for the lower parts of the valleys show elevated levels of coarser material, here coarse sands and gravels. The frequency curves for the upper parts display two main modes corresponding to the fractions of medium and fine sands. A more distinct mode in the coarser fraction shows the supply of this material to prevail in the heads of the valleys. It was also observed that deposits in the outlet sections were poorer sorted than those in the upper parts.

The sand lithofacies was analysed for the abrasion grade of quartz grains using Krygowski's
(1964) mechanical graniformametry method. In the light of his typology, the most frequent quartz grains in the deposits are those of type a, characterised by very low abrasion. This type of quartz grains of the sand fraction is characteristic, among other things, of glacial environments, which are enriched with cracked grains or ones without abrasion. In this environment the grains do not alter the character of the surface; rather, they undergo conservation (Goździk \& Mycielska-Dowgiałło 1982). The abrasion grade of quartz grains of sand plays an important role in the genetic and dynamic interpretation of Quaternary deposits (Mycielska-Dowgiałło \& Woronko 1998). It allows drawing conclusions about processes working on the deposits and conditions holding in the period preceding their deposition and transport.

The examination of the abrasion grade of quartz grains shows a marked bimodality of the distribution and a considerable predominance of grains of type $\beta$, i.e. ones of a medium level of abrasion. The bimodality shows in a great proportion of angular material (type a, up to 60\%) and intermediate one (type $\beta$, up to $40 \%$ ). Such a distribution of the grain mass is indicative of admixtures from various environments, as pointed out by Kostrzewski (1971). The observed predominance of grains of type $\beta$ can even exceed $90 \%$; such a high proportion of this type of grains may additionally indicate a substantial degree of aeolisation of the mineral material. Differences in the abrasion grade of grains are easy to observe when expressed by the abrasion index $\mathrm{W}_{\mathrm{o}^{\prime}}$ which assumes values in excess of 1000 for deposit samples with a high content of grains of type $\beta$.

\section{A reconstruction of the dynamics of denudational processes}

Late Vistulian slope processes started in the uplands of the Dębnica valley region after the recession of the last inland ice, i.e. about $15 \mathrm{ka} \mathrm{BP.}$ With its retreat, waters flowing in marginal valleys changed course towards the north, cutting successive younger marginal zones and creating water-gaps. In turn, the melting of dead-ice blocks started the inclusion of subglacial tunnel valleys, terminal basins and melt-out basins 

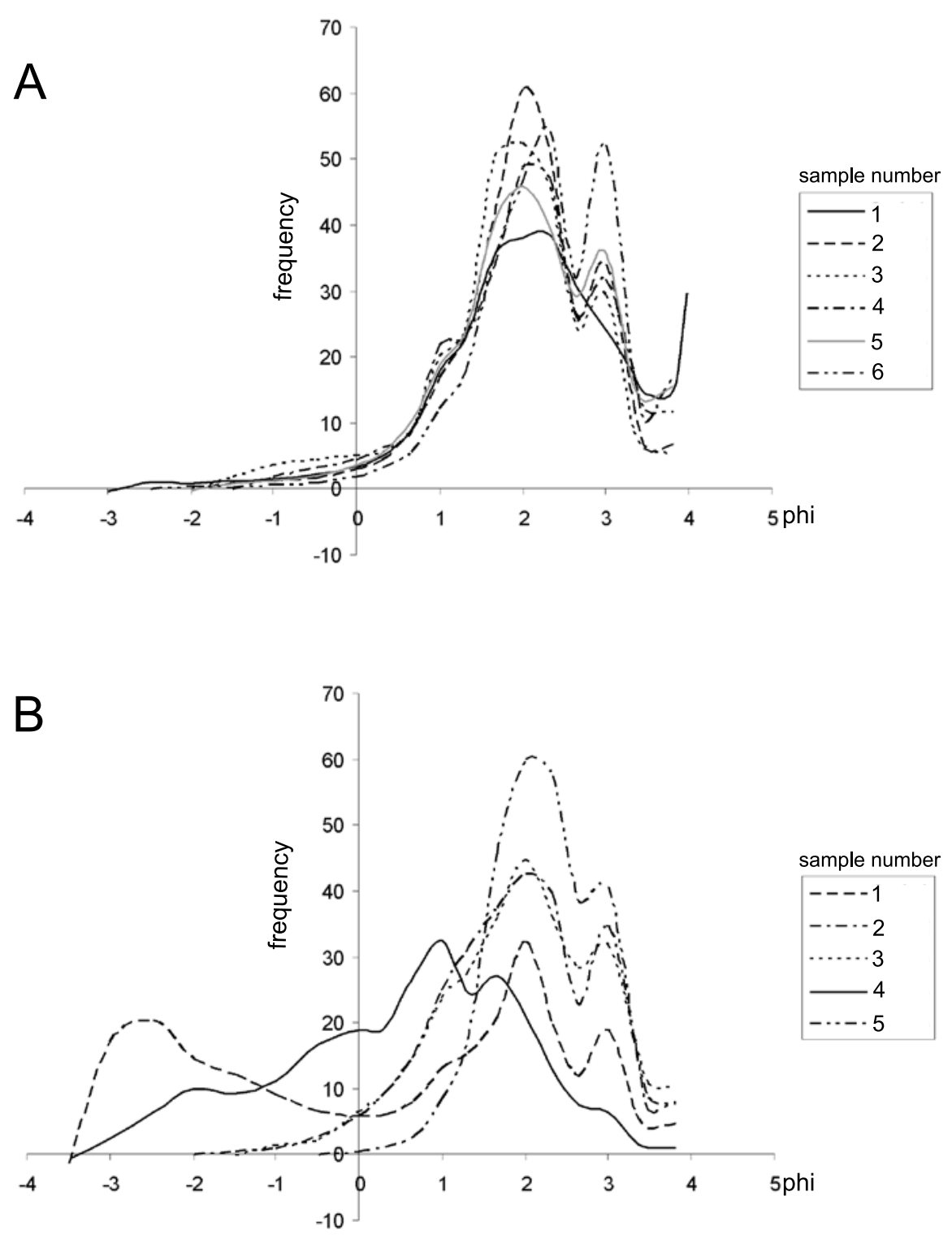

Fig. 5. Examples of frequency curves for the upper sections of the valley (A) and lower sections of the valley (B) (Dębnica valley, West Pomerania).

into the river system (Florek 1991; Błaszkiewicz 1998, 2005). The final stage of dead-ice melting saw a reorientation of the direction of meltwater flow towards the Białogard basin in the north. As a result of heavy bottom and lateral erosion, there developed a broad meltwater channel in the Dębnica trough with a system of three levels of cut-and-built terraces. Towards the end of the Pleistocene there formed a terrace above the Dębnica floodplain and small hillocks of dunes (Dobracka, 2009). Along the upland scarps numerous denudational valleys developed, later filled with diluvial material.
Because of insufficient evidence in deposits, the stages of formation of the valleys were reconstructed with the help of the literature on the subject. Presumably, the first stage can be dated to the Oldest Dryas. As Kozarski (1995) claims, at that time the climate in northern Poland was cold and dry, with a mean annual temperature of $-1^{\circ} \mathrm{C}$ favourable to the persistence of permafrost. The predominant type of vegetation was dwarf-shrub tundra (Tobolski 1998). In such conditions, there was intensive denudation in the upper parts of the valleys (Maruszczak 1968), while solifluction predominated in the lower sections in the north. 
When describing the evolution of valleys and hollows on the slopes of the Warta-Noteć Pradolina, Churska (1965) observes that what could be an impulse for the development of erosional hollows were cracks in the land surface, and in the case of dry valleys, mass movement on the slopes, but with water flowing down the slopes and along their axes as the dominant factor. In turn, for Marsz $(1964,1995)$ the first stage of development of valleys dissecting the scarp of the Kashubian Pradolina involved the appearance of hollows produced by erosion and intensive denudation that accompanied it. One of the chief processes initiating the formation of the valleys studied was the erosional action of water flowing down the slopes. Also Gołębiewski (1981) believed erosion to have played a major role in the first period of development of dry valleys.

In the Bölling, owing to the degradation of permafrost in entire central Europe, the role of solifluction in the modelling of the valleys declined sharply (Kozarski 1995), which was due, among other things, to the appearance of a compact plant cover. In the central part of north-western Poland, it was already in the Bölling that an initial birch-dominated forest appeared (Tobolski 1998). A dense plant cover certainly also greatly reduced slope wash in the valleys. The process that crucially contributed to their development was erosion advancing along their floors. Its intensity could be due to great amounts of water from the melting permafrost, which survived in the ground despite the Bölling warming (Kozarski \& Nowaczyk 1995). The gradual advance of a compact plant cover effectively reduced the supply of material along the slopes, which in turn made destructive action easier. A visible indication of Bölling erosion is the erosional pavement found in the valleys in the form of gravel-stone levels. Among the authors who wrote about erosional stages within dry valley landforms in periods of climate amelioration and increased humidity are Klatkowa (1965), and about erosion in the Bölling, Marsz (1964) and Maruszczak (1968).

In the short cold stage of the Older Dryas, as Ralska-Jasiewiczowa \& Starkel (1991) claims, the advance of forest formations could stop, or even suffer a reversal. The role of erosion in the shaping of the valleys weakened, also as a result of climate change. This could result in the valley floors becoming covered with deposits deriving primarily from wash. A short-lived increase in the role of accumulation in the colder stage is also mentioned by Maruszczak (1968). In the erosional-denudational valleys under study it is hard to identify with any certainty slope series whose formation might be connected with the Older Dryas.

In the Alleröd, erosion comes to prominence again in the formation of the valleys (Marsz 1964,1995; Maruszczak 1968), facilitated by a very small supply of material from the catchments of the valleys owing to the presence of the plant cover and an increase in humidity. Erosion was the heaviest during intensive rainfalls in the lower and middle parts of the valleys, which was certainly connected with the considerable gradient of their long profile in the middle sections.

In the Younger Dryas the role of denudation in slope formation increased again. The material transported downslope accumulated on the valley floors (Marsz 1964, 1998; Maruszczak 1968). There developed thin covers of slope deposits of a much smaller extent than in the Oldest Dryas. It was a period of marked cooling and a drop in humidity, which activated slope processes in the already well-developed valleys and reduced erosion along their floors. Conditions at the Late Vistulian-Holocene boundary - a climatic warming, an increase in humidity - could make slope processes more intensive (Ralska-Jasiewiczowa et al. 2003). Presumably, there could also still appear solifluction because of the shallow-lying permafrost. The appearance of man and his economic activity - slash-and-burn agriculture and land cultivation - contributed to the activation of slope processes in the younger Holocene. From the beginning of the Holocene to the start of human settlement, slope deposits were almost completely absent, as found by e.g. Starkel (1989), Borówka (1992, 1994), Twardy (2000), and Smolska (2003). Neo-Holocene diluvial deposits appear in only those landforms near which man carried out his economic activity.

In one of the erosional-denudational valleys of the Piaski Pomorskie scarp zone, peat deposits lying at a depth of $1 \mathrm{~m}$ below ground-level were dated using the ${ }^{14} \mathrm{C}$ method. The exposure was situated in the distal part of the alluvial cone. The analysis embraced three samples: the bottom of 
the peat deposits was dated to $2100 \pm 30 \mathrm{BP}$ (Poz22990, calibrated to 198BC (95.4\%) 46 BC using the OxCal program), the central part, to $1965 \pm 35$ BP (Poz-229910, 44 BC (91.0\%) 88 AD), and the top, to $1835 \pm 35 \mathrm{BP}$ (Poz-22992, $81 \mathrm{AD}$ (95.4\%) $253 \mathrm{AD})$. The content of organic matter in the samples exceeded $80 \%$. The above ${ }^{14} \mathrm{C}$ dates show the valley to have formed in the Sub-Atlantic period. When correlating them with archaeological studies conducted in Central Pomerania, one can find that in the Roman period the lands near the examined valleys were densely inhabited by people of the Wielbark culture (Machajewski 2006). At that time the chief factor activating slope processes was human activity.

\section{Conclusions}

The research conducted in West Pomerania made it possible to identify tens of erosionaldenudational valleys located within morainic uplands. Those on the morainic upland discussed in this article are landforms in which Late Vistulian erosion only rejuvenated the already existing older forms. They are valley systems following an old pattern. Their geomorphological characteristics presented in the article allow some generalisations. They are small landforms whose length does not exceed $100 \mathrm{~m}$, and the depth of incision attains up to $4 \mathrm{~m}$. In their long profile the following parts can be distinguished: valley head - narrow-floor section - widening outlet section - alluvial fan. Alluvial fans of the valleys under analysis are not prominent features of the relief. The most incised middle segments of the valleys have sides with the steepest slope angle, even in excess of $26^{\circ}$. In deposits, where the dominant fraction is fine sand, there is a marked zone of erosion pavement - a stone-gravel layer which is a barrier to further lowering of the erosion base of the valleys. In view of the nature of the deposits, the basic processes modelling the development of the valleys must be those of wash and erosion. Today, the deforestation of their scarp zones significantly limits further development of the valley landforms, and their dry floors are largely shaped by episodic water flows.

\section{Acknowledgment}

This paper is supported by the founds intendend by Polish Ministry of Science and Higher Education for science in years 2007-2010 as research project No N 306012 32/0865.

\section{References}

BŁASzKIEWICZ M., 1998. Dolina Wierzycy jej geneza oraz rozwój w późnym plejstocenie i wczesnym holocenie. Dok. Geogr. 10.

BŁAszKIEWicz M., 2005. Późnoglacjalna i wczesnoholoceńska ewolucja obniżeń jeziornych na Pojezierzu Kociewskim (wschodnia część Pomorza). Pr. Geogr. IGiPZ PAN 201.

BoróWKA R.K., 1992. Przebieg $i$ rozmiary denudacji w obrębie śródwysoczyznowych basenów sedymentacyjnych podczas późnego vistulianu i holocenu. UAM, seria Geografia 54, Poznań.

BorówKA R.K., 1994. Naturalne i antropogeniczne uwarunkowania zmian denudacji podczas holocenu. Rocz. AR 266: 27-37. Poznań.

Churska Z., 1965. Późnoglacjalne formy denudacyjne na zboczach pradoliny Noteci-Warty i doliny Drwęcy. Stud. Soc. Scient. Torun., Sec. C, Geogr. et Geol. 6: 112.

DoBRACKA E., 2009. Objaśnienia do szczegółowej mapy geologicznej Polski w skali 1: 50 000. Arkusz Połczyn Zdrój (158).

DYLIK J., 1953. O peryglacjalnym charakterze rzeźby środkowej Polski. Acta Geogr. Lodz. 4.

FLOREK W., 1991. Postglacjalny rozwój dolin rzek środkowej części pótnocnego skłonu Pomorza. WSP, Słupsk.

GoŁęBIEWsKI R., 1981. Kierunki i intensywność denudacji na obszarze zlewni Raduni w późnym würmie i holocenie. Zesz. Nauk. UG, Rozprawy i Monografie 26. Gdańsk.

GoźDzIK J., MycielsKa-DowgIAŁŁo E., 1982. Badania wpływu niektórych procesów geologicznych na przekształcenia powierzchni ziarn kwarcowych. Przegl. Geol. 54(3): 219-241.

JAHN A., 1956. Wyżyna Lubelska. Rzeźba i czwartorzęd. Pr. Geogr. IG PAN 7.

KARCZEWSKI A., 1989. Morfogeneza strefy marginalnej fazy pomorskiej na obszarze lobu Parsęty w vistulianie (Pomorze Środkowe). Wyd. Nauk. UAM, Poznań: 48.

KlatKowa H., 1965. Niecki i doliny denudacyjne w okolicach Łodzi. Acta Geogr. Lodz. 19.

Kondracki J., 2000. Geografia fizyczna Polski. PWN, Warszawa.

KostrzewsKi A., 1963. Morfologia ostrowskiej wyspy wysoczyznowej pod Gostyniem. Bad. Fizjogr. nad Pol. Zach. 11: 191-202.

KostrZEwSKi A., 1971. Niecki denudacyjne w krawędzi wysokiej terasy ujściowego odcinka doliny Bobru. Bad. Fizjogr. nad Pol. Zach. 24: 77-95.

KozARSKI S., 1995. Deglacjacja północno-zachodniej Polski: warunki środowiska i transformacja geosystemu ( 20 ka $\rightarrow 10$ ka BP). Dok. Geogr. 1 .

KozArski S. \& NowAczyK B., 1995. The Boling Interstadial at Żabinko and Late Vistulian environmental changes in the middle reach of the Warsaw-Berlin pradolina. Quater. Stud. in Poland 13: 43-53. 
KRYGowsKi B., 1964. Graniformametria mechaniczna. Teoria, zastosowania. Pr. Kom. Geogr.-Geol. PTPN 4.

LEWANDOWSKI J. \& NITA M., 2008. Ewolucja systemu hydrograficznego i szaty roślinnej dorzecza górnej Piławy i górnej Drawy (Pomorze Środkowe). Przegl. Geol. 56(5): 380-390.

Machajewski H., 2006. Pomorze Środkowe w okresie rzymskim i we wczesnej fazie okresu wędrówek ludów. In: W. Nowakowski (ed.), Goci na Pomorzu Środkowym. Koszalin: 35-63.

MARUSZCZAK H., 1956. Główne cechy klimatycznej asymetrii stoków w obszarach peryglcjalnych i umiarkowanych. Ann. UMCS 11(5): 161-207.

MaruszczaK H., 1968. Procesy denudacyjne w późnym glacjale i holocenie w świetle badań suchych dolin w Polsce. Folia Quater. 29: 79-87.

Marsz A., 1964. O rozcięciach erozyjnych krawędzi Pradoliny Kaszubskiej między Gdynią a Redą. Bad. Fizjogr. nad Pol. Zach. 13: 113-154.

MArsz A., 1995. Rozmiary erozji i denudacji późnoglacjalnej na północnym skłonie Pojezierza Kaszubskiego i Pobrzeżu Kaszubskim. In: W. Florek (ed.), Geologia i geomorfologia Pobrzeża i potudniowego Battyku. 2. WSP, Słupsk: 139-152.

MARsz A., 1998. Geneza i zanik ochłodzenia globalnego w późnym glacjale jako efekt współdziałania w systemie zlodowacenie-ocean-atmosfera. In: J. Repelewska-Pękalowa (ed.), IV Zjazd Geomorfologów Polskich „Rzeźba, paleogeografia czwartorzędu oraz problemy zmian środowiska obszarów polarnych", Lublin: 89-96.

Mazurek M., Paluszkiewicz R. \& Piotrowska I., 2010. Walory turystyczne sieci dolinnej w dorzeczu Parsęty. Krajobraz a turystyka. Pr. Kom. Krajoz.-Kultur. PTG 14: 207-220.

MoJSKI J.E., 1950. Asymetria zboczy dolinnych w dorzeczu Bystrzycy. Ann. UMCS V(2): 27-49.

Mycielska-Dowgialto E. \& Woronko B., 1998. Analiza obtoczenia i zmatowienia powierzchni ziarn kwarcowych frakcji piaszczystej i jej wartość interpretacyjna. Przegl. Geol. 46(12): 1275-1281.

Окоєошісz W., 1947. Rekonstrukcja klimatu i jego zmian na podstawie morfologii terenu. Przegl. Geogr. 21(1-2): 83-91.

Paluszkiewicz R., 2007. Charakterystyka geomorfologiczna strefy krawędziowej w obrębie Pomorza Zachodniego (na przykładzie okolic Piaski Pomorskie). In: E. Smolska, P. Szwarczewski (eds.), Zapis działalności człowieka w środowisku przyrodniczym, IV: 105-108.
Paluszkiewicz R., 2008. Charakterystyka osadów stożka napływowego suchej dolinki erozyjno-akumulacyjnej Piaski Pomorskie (Pomorze Zachodnie). Landform Analysis 9: 68-71.

PALUSZKIEWICZ R., 2009. Zróżnicowanie litologiczne osadów dolinek erozyjno-denudacyjnych (Pomorze Zachodnie). In: A. Kostrzewski, R. Paluszkiewicz (eds.), Geneza, litologia i stratygrafia utworów czwartorzędowych. 5. Seria Geografia 88: 383-406.

PŁochNIEWSKI Z., 1986. Hydrogeologia i geologia inżynierska. Wyd. Geol., Warszawa.

Racinowski R., 1973. Analiza uziarnienia. In: E. Ruhle (ed.), Metodyka badań osadów czwartorzędowych. Wyd. Geol., Warszawa: 331-335.

RalSKa-JASIEWicZOWA M. \& StARKel L., 1991. Ewolucja szaty roślinnej. In: L. Starkel (ed.), Geografia Polski. Środowisko przyrodnicze. PWN, Warszawa: 177-182.

Ralska-Jasiewiczowa M., Goslar T., RÓŻański K., Wacnik A., Czernik J. \& Chróst L., 2003. Very fast environmental changes at the Pleistocene/Holocene boundary, recorded in laminated sediments of Lake Gościa, Poland. Paleogeography, Paleoclimatology, Paleoecology 193: 225-247.

Starkel L., 1989. Antropogeniczne zmiany denudacji i sedymentacji w holocenie na obszarze Europy Środkowej. Przegl. Geogr. 61(1-2): 25-32.

SmOlSKa E., 2002. Denudacja antropogeniczna - zapis w rzeźbie i osadach na wybranych przykładach z obszaru Pojezierza Suwalskiego. In: P. Szwarczewski, E. Smolska (eds.), Zapis działalności człowieka w środowisku przyrodniczym, 1: 113-119.

SmOlSKa E., 2003. Współczesne i holoceńskie tempo denudacji stoków Pojezierza Suwalskiego. In: R. Gołębiewski (ed.), Ewolucja Pojezierzy i Pobrzeży Południowobattyckich. Gdańsk: 111-119.

Toвolski K., 1998. Stan poznania historii lasów, jezior i torfowisk Borów Tucholskich. In: J. Banaszak, K. Tobolski (eds.), Park Narodowy Bory Tucholskie. WSP, Bydgoszcz: 19-48.

SZPIKOWSKI J., 2005. Zapis denudacji antropogenicznej w katenach stokowych zlewni Perznicy (dorzecze Parsęty). In: A. Kotarba, K. Krzemień, J. Święchowicz (eds.), Współczesna ewolucja rzeźby Polski. VII Zjazd Geomorfologów Poskich, Kraków: 431-437.

TRICART J., 1950. Cours de géomorphologie. Géomorphologie climatique. Le modelé périglaciaire I. Paris.

Twardy J., 2000. Dynamika denudacji holoceńskiej w strefie krawędziowej Wyżyny Łódzkiej. Acta Geogr. Lodz. 69. 